\title{
lloprost modulates the immune response in systemic sclerosis
}

\author{
Patrizia D’Amelio ${ }^{1 *}$, Maria A Cristofaro ${ }^{1}$, Lucia D’Amico $^{2}$, Luciana Veneziano $^{1}$, llaria Roato ${ }^{2}$, Francesca Sassi ${ }^{1}$, \\ Giuseppina Bisignano ${ }^{1}$, Marta Saracco ${ }^{3}$, Raffaele Pellerito ${ }^{3}$, Salvatore Patanè2 ${ }^{2}$ Riccardo Ferracini ${ }^{2,4}$, \\ Gian P Pescarmona ${ }^{2,5}$, Giovanni C Isaia ${ }^{1}$
}

\begin{abstract}
Background: lloprost has been suggested to possess anti-inflammatory and immunomodulating actions and it is widely use as a vasodilatator in systemic sclerosis (SSc). In this study we evaluate the effect of iloprost on immune response in SSC patients. To this extend we enrolled 15 women affected by SSC and infused iloprost for 5 days. The effect of iloprost on T cells and monocytes was measured by flow cytometry, Real time PCR and measuring cytokines production in vivo and in vitro by ELISA.
\end{abstract}

Results: Our results demonstrate that lloprost reduces T cell and TNF alpha production both in vivo and in vitro. It reduces $T$ regulatory cells number, but increases their activity after immune stimulation. It increases serum IL-2 and this increase persists 28 days after the last infusion, also RANKL was increased both in vivo and in vitro. We observed no effect on IFN gamma production.

Conclusions: These results suggest that iloprost has anti-inflammatory and immunomodulating effects, reducing TNF alpha production by T cells and the number of T regulatory cells and increasing IL-2 and RANKL.

\section{Background}

Systemic sclerosis (SSc) is a disease whose extremely complex, multifaceted pathogenesis cannot be referred to a single hypothesis, even if fundamental abnormalities in three or more types of cells are involved: fibroblasts, endothelial cells and cells of the immune system, namely $\mathrm{T}$ and B lymphocytes [1]. Mononuclear cells (mainly $\mathrm{T}$ cells) in the SSc skin infiltrates produce cytokines and growth factors responsible for the onset and progression of fibrosis and microvascular damage. The role of this immune dysfunction is not fully clear. Altered cellular immunity is revealed by aberrant $\mathrm{T}$ cell biology in both the skin, where the lesions display various features consistent with $\mathrm{T}$ cell activation [2-4], and the circulation, where $\mathrm{CD} 4+\mathrm{T}$ cells are increased $[2,5]$, and natural killer $\mathrm{T}$ cells are decreased [6]. Lastly, circulating $\mathrm{T}$ cells from SSc patients produce more inflammatory mediators compared to those from healthy controls $[7,8]$.

\footnotetext{
* Correspondence: patrizia.damelio@unito.it

'Gerontology Section, Department of Surgical and Medical Disciplines, University of Torino, Italy

Full list of author information is available at the end of the article
}

An important role as controllers of self-reactivity [9] has recently been defined for $\mathrm{T}$ regulatory cells (Treg) in autoimmune disease. These cells are defined as $\mathrm{CD} 4+1$ $\mathrm{CD} 25^{\text {bright }} / \mathrm{FoxP} 3+$. In SSc, both an increase in their absolute number and a reduction of their function have been demonstrated [10].

A high proportion of SSc patients suffer from Raynaud's phenomenon. This is a vasospastic disorder that causes discoloration of the fingers, toes and occasionally other extremities, and its persistence may result in acral ulcer and significantly reduce the quality of life [11]. Prostaglandin (PG) analogues, particularly the PGI2 analogue iloprost, are widely used as vasodilators to treat this disorder [12].

Patients with SSc receiving Iloprost report a reduction in skin tightness, suggesting that this drug inhibits skin fibrosis. It has been suggested that iloprost reduces skin fibrosis by reducing collagen synthesis $[13,14]$, the profibrotic cytokine connective tissue growth factor [15] and the fibrotic response [16].

Iloprost has since been shown to possess antiinflammatory and immunomodulating actions, both in vitro [17-20] and in vivo [21-24]. Of the two studies in
C Biomed Central

(ㄷ) 2010 D'Amelio et al; licensee BioMed Central Ltd. This is an Open Access article distributed under the terms of the Creative Commons Attribution License (http://creativecommons.org/licenses/by/2.0), which permits unrestricted use, distribution, and reproduction in any medium, provided the original work is properly cited. 
humans [21,22], only Filaci et al. [22] evaluated the effect of iloprost in SSc. Its potential in this disease is thus an open question.

Here we demonstrate that iloprost decreases the production of TNF $\alpha$ by acting on T cells, ameliorates Treg function, and increases IL-2.

\section{Methods}

\section{Patients}

The study was approved by the "Clinical Study Review Committee" of Turin's "Ordine Mauriziano" Hospital, and all the patients signed an informed consent statement prior to their recruitment.

Fifteen women with SSc aged $53 \pm 11$ (7 in postmenopause) were enrolled. None were taking corticosteroids, estrogen, or immunosuppressants, or had previously received iloprost. Their SSc was classified as grade I accordng to Medsger et al. [17] and its mean duration was $26 \pm 17$ months. Raynaud's phenomenon was always present. All the patients complained of sideeffects, but continued the infusions and reached satisfactory drug levels. The mean quantity infused was $0.8577 \pm$ $0.1722 \mathrm{ng} / \mathrm{Kg} / \mathrm{min}$ for $6 \mathrm{hrs} /$ day for 5 days. All the patients started a second iloprost course after 28 days.

\section{Treatment}

Iloprost was infused intravenously according to the standard protocol [11] for $6 \mathrm{~h} /$ day for 5 consecutive days. The target dose was $2 \mathrm{ng} / \mathrm{kg} / \mathrm{min}$.

Blood was drawn from an antecubital vein after an overnight fast of 10 or more hours at baseline, after the 5 -day treatment, and then after a further 28 days to evaluate the timing of its action; 28 days were chosen since in clinical practice another course is started at the end of this period.

All measurements were performed from a single blood sample at a single time point per patient.

\section{Media, reagents, and chemicals}

Cells were maintained in RPMI 1640 (Sigma-Aldrich, St Louis MO) supplemented with $2 \mathrm{mM} \mathrm{L}$-glutamine $10 \%$ fetal bovine serum (FBS), benzyl penicillin $(100 \mathrm{IU} / \mathrm{ml})$ and streptomycin $(100 \mu \mathrm{g} / \mathrm{ml})$, phytohemoagglutinin (PHA: Sigma-Aldrich, St Louis MO.) was added in the stimulated condition.

IL-2 was purchased from R\&D Systems (Minneapolis, MN, USA). Iloprost ([100 ng/ml], was kindly provided by Italfarmaco, Italy).

\section{Cells}

Peripheral bood mononuclear cells (PBMCs) from SSc patients were obtained with the Ficoll-Paque method from $40 \mathrm{ml}$ peripheral blood in lithium heparin at baseline, after 5 days iloprost infusion, and at 28 days after the last infusion. PBMC cultures were performed in triplicate for each subject in 96-well plates $\left[1 \times 10^{5}\right.$ cell/ well]. For in vitro experiments PBMCs were obtained from buffy coats (five independent experiments).

$A b$

Fluorescein (FITC) conjugated anti-CD25, phycoerythrin (PE) conjugated anti-CD69 PE-conjugated anti-TNF $\alpha$ were purchased from Biolegend (San Diego, CA).

Peridinin chlorophyll protein (PeRCP) conjugated antiCD3 was purchased from Becton \& Dickinson (Bedford, MA).

$\mathrm{T}$ reg staining kit and $\mathrm{APC}$-conjugated anti-CD14 were purchased from eBioscience (San Diego, CA).

\section{Flow cytometry}

For intracellular staining, brefeldin $([10 \mu \mathrm{g} / \mathrm{mL}]$, SigmaAldrich, St. Louis, MO) was added to the cells for $1 \mathrm{hr}$. Cells were harvested, stained with surfaces antibodies, then permeabilized with saponin 5\% (Sigma-Aldrich, St. Louis, MO) for 20 min washed and blocked for nonspecific binding sites using normal rat serum before the intracytoplasmic staining (TNF $\alpha$ and FoxP3) was performed. All the experiments were performed with cells stained with specific isotype control.

Flow cytometry was performed on a FACSCalibur flow cytometer (Becton Dickinson, Franklin Lakes, NJ, USA).

\section{Cytokine measurement}

Serum IL-2 (Bender Med System, Vienna, Austria), total RANKL (BioVendor, madrice, Czech Repubblic), TNF $\alpha$ (DuoSet, R\&D System Inc, Minneapolis, MN) and TGF $\beta 1$ (DuoSet, R\&D System Inc, Minneapolis, MN) were measured by ELISA. The levels of TNF $\alpha$, free RANKL, TGF $\beta 1$ and INF $\gamma$ (Bender Med System, Vienna, Austria) were also measured in the supernatants from cultures stimulated or not with PHA.

\section{Real time RT-PCR}

Total cellular RNA was isolated using TRIzol reagent (Ambion, Huntingdon, UK), chloroform extraction, and subsequent isopropanol precipitation according to the manufacturer's protocol. $1 \mu \mathrm{g}$ of RNA was converted up to single-stranded cDNA by the High-Capacity cDNA Reverse Transcription Kit (Applied Biosystems, Warrington, UK). cDNA was stored at $-20^{\circ} \mathrm{C}$ until use. $\beta$-Actin was the housekeeping control. RQ-PCR analysis of RANKL and TGF $\beta 1$ was performed by the $\mathrm{iCycler} \mathrm{iQ}^{\mathrm{m}}$ system (Bio Rad, Hercules, CA, USA). TaqMan probes were designed using Primer Express v2.0 software and synthesized by Applied Biosystems (Warrington, UK). FoxP3 expression was quantified by the Syber Green method. The following primers were used: RANKL sense 5'-GCCTTTTGCTCATCTCACTATTAATG-3' and 
antisense 5'-TGGTACCAAGAGGACAGACTCACTT-3'; TGF-b sense 5' - TTTGATGTCACCGGAGTTGTG-3' and antisense 5'- GCGAAAGCCCTCAATTTCC-3'; FOXP3, sense 5'-CAGCTGCTCGCACAGATTACTT-3' and antisense 5'-GGGACAGGATTGTGACATTTTGT-3'.

\section{Statistics}

The normal distribution of each parameter was determined with Kurtosis' test: PBMC subsets, the cytokines (except for serum IL-2, serum RANKL and TGF $\beta$ in the supernatants) and genes measured were normally distributed. Student's paired t test was used to compare gaussian variables at baseline and after iloprost (5 and 28 days). Wilcoxon's test was used to compare non-gaussian variables at baseline and after iloprost (5 and 28 days).

The SPSS 17.0 software package was used to process the data with $\mathrm{p}<0.05$ as the significance cut-off.

\section{Results}

\section{lloprost reduces T cell and TNF $\alpha$ production}

Involvement of iloprost in control of the immune response and inflammation has been suggested [18-23], though there are no data indicative of this effect in SSc.

1A illustrates the significant reduction of $\mathrm{T}$ cells achieved after 5 days of lloprost, whereas monocytes are not affected. $T$ cells returned to the baseline level 28 days after the last infusion. As TNF $\alpha$ is produced mainly by $\mathrm{T}$ cells and monocytes among PBMCs and it is increased in inflammation, we looked at the effect of iloprost on TNF $\alpha$ producing cells. Figure 1B shows that TNF $\alpha$ producing $\mathrm{T}$ cells decreased after 5 days of iloprost and returned to baseline 28 days after the last infusion, whereas TNF $\alpha$ producing monocytes were not affected.

These findings could reflect diminished $\mathrm{T}$ cell activation, but evaluation of the early and late $\mathrm{T}$ cell activation

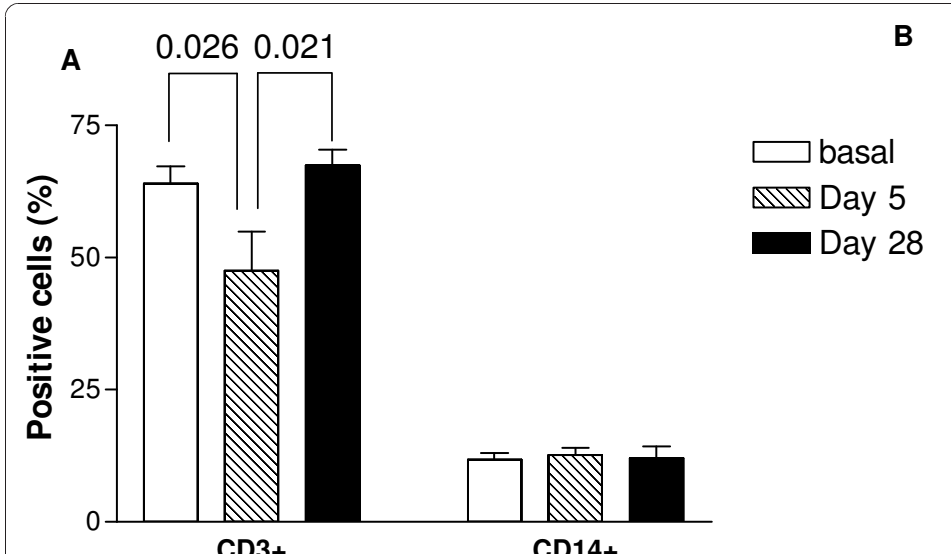

C

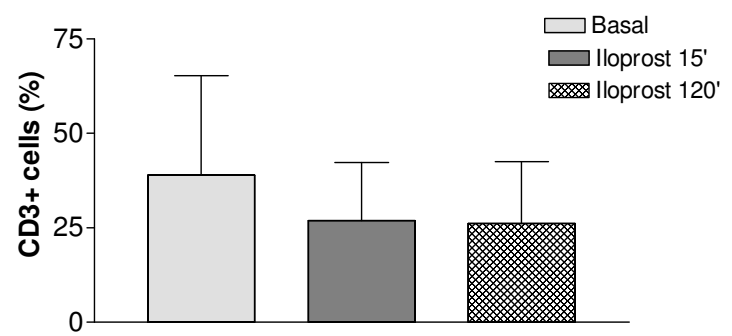

B

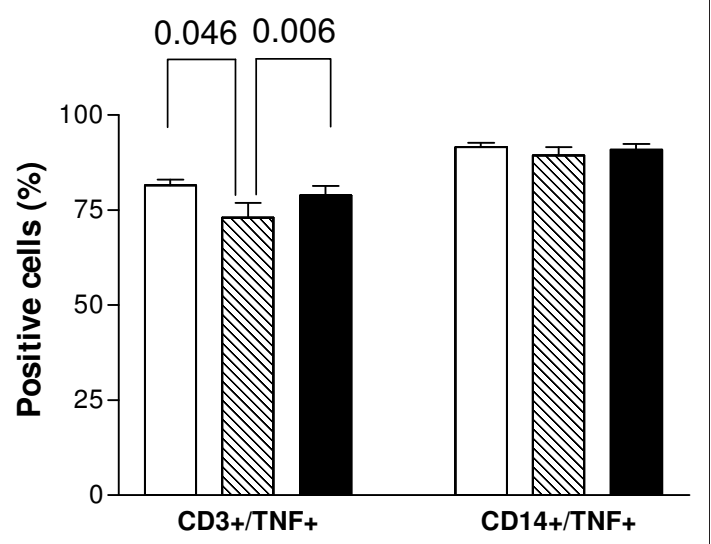

Figure 1 Iloprost reduces T cells. PBMCs isolated from SSC patients at baseline and after treatment with iloprost (5 days of daily treatment, 28 days after the last infusion) were analysed by flow cytometry to evaluate T cells, monocytes, TNF $\alpha$ production and degree of T cell activation. A. Graph shows the percentage of T cells (CD3+) and of monocytes (CD14+) among PBMCs. Bars represent mean and SD for all the patients, $p$ values were calculated by a paired Student's t test, significant values are displayed. B. Graph shows the percentage of TNF $\alpha$ producing T cells (CD3+, gated on lymphocytes) and monocytes (CD14+, gated on monocytes). Bars represent mean and SD for all the patients, $p$ values were calculated by a paired Student's t test, significant values are displayed. C. In vitro challenge of PBMCs culture with iloprost for 15 and 120 min. Graph shows the percentage of T cells (CD3+) in PBMCs. Bars represent mean and SD of five independent experiments. The reduction is not statistically significant. 
markers CD69 and CD25 disclosed at non significant reduction of such activation (data not shown).

To determine whether iloprost reduces $\mathrm{T}$ cells directly, we incubated PBMCs from buffy coats (five experiments) with iloprost. Figure $1 \mathrm{C}$ suggests that iloprost might reduce the number of $\mathrm{T}$ cells in vitro, even though the results are not statistically significant.

Confirmation of iloprost's anti TNF $\alpha$ effect was sought by measuring TNF $\alpha$ levels in supernatants from PBMC cultures stimulated or not with PHA. As expected, PHA increased TNF $\alpha$ secretion. Iloprost reduced this response and hence the production of TNF $\alpha$ (Figure 2A), whereas it had no effect on TNF $\alpha$ in the unstimulated culture (Figure 2B). We found no decrease in serum TNF $\alpha$ after iloprost (data not shown). This datum points to the specific action of iloprost against $\mathrm{T}$ cells and its ability to reduce TNF $\alpha$ production in response to $\mathrm{T}$ cell stimulation.

\section{lloprost reduces $\mathrm{T}$ regs in vivo and in vitro}

Since altered Treg number and activity may be important in SSc [10], we evaluated these cells as a possible iloprost target. We studied $\mathrm{T}$ cells by flow cytometry and confirmed our data by analysing FoxP3 expression by real time RT-PCR. Figure 3A \&3B demonstrate a reduction of Treg cells after 5 days of iloprost infusion.

TGF $\beta 1$ is mainly produced by Treg cells within PBMCs and it is a marker of their function $[28,29]$, we measured this cytokine in the PBMCs culture supernatants at baseline and after iloprost with and without immune stimulation. The data in Figure 4A show a significant increase in TGF $\beta 1$ in the PBMCs supernatants after stimulation with PHA following iloprost, hence

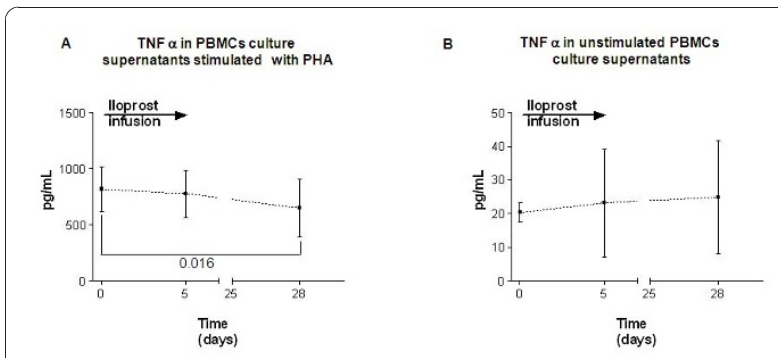

Figure 2 lloprost treatment reduces TNF $\alpha$ production from PBMCs after stimulus with PHA. TNF $\alpha$ was measured in the culture supernatants of PBMCs from SSC patients treated with iloprost at baseline and after treatment ( 5 days of daily treatment, 28 days after the last infusion), cultures were stimulated or not with PHA which predominantly stimulates T cells. A. Graph shows the level of TNF $\alpha$ supernatants 24 hrs after stimulus with PHA. Symbols represent mean and SD for all the patients, $p$ values were calculated by paired Students' T test, significant values are displayed. B. Graph shows the level of TNF $\alpha$ supernatants without PHA. Symbols represent mean and SD, for all the patients.

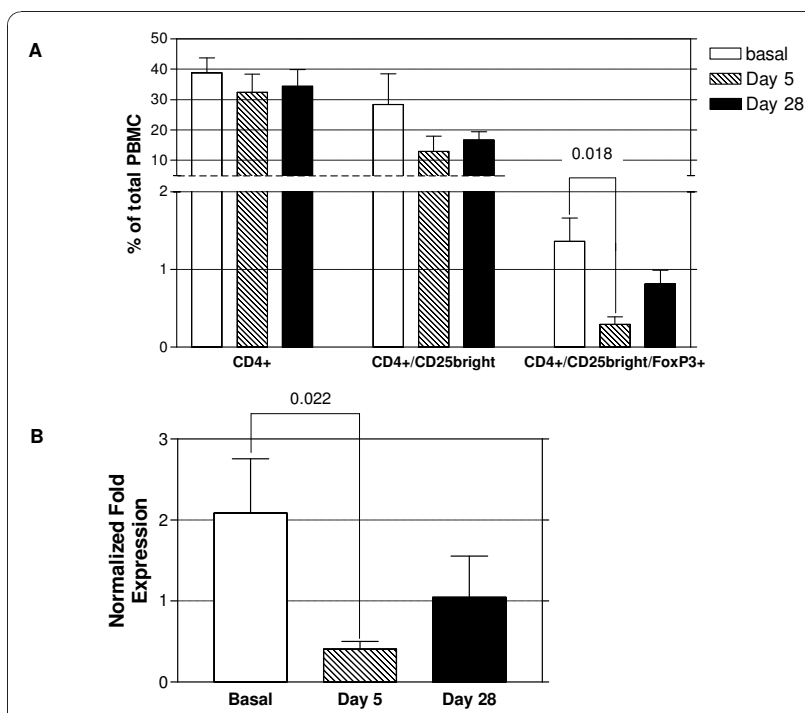

Figure 3 lloprost reduces Tregs. PBMCs isolated from SSC patients at baseline and after treatment with iloprost ( 5 days of daily treatment, 28 days since the last infusion) were analysed by flow cytometry to evaluate Tregs (CD4+/CD25bright/FoxP3+

lymphocytes) and by real time PCR to evaluate FoxP3 expression. A. Graph shows the percentage of Tregs in PBMCs. Bars represent mean and SD for all the patients, $p$ values were calculated with Student's paired t test, significant values are displayed. B. Graph shows FoxP3 expression in PBMCs from patients at baseline and after treatment. The FoxP3 expression was corrected for expression of the housekeeping gene $\beta$ actin. Bars represent mean and SD for all the patients, $p$ values were calculated with Student's paired $t$ test, significant values are displayed.

suggest that iloprost influences the response of Treg cells to immune stimulation.

Serum TGF $\beta 1$ is not influenced by iloprost (data not shown): this datum points to a specific action of iloprost against T cells producing TGF $\beta 1$, the Treg as TGF $\beta 1$ is produced by a variety of other cells in vivo.

Increased TGF $\beta 1$ expression was also corroborated by real time PCR experiments on PBMCs incubated with iloprost for 15' and 120' in the presence or absence of PHA (Figure 4B).

Treg cells are mainly involved in maintenance of selftolerance, which is disrupted in SSc as in other immune disorders $[9,10,30,31]$. Our data suggest that iloprost can enhance self tolerance and hence be useful in the treatment of SSc.

\section{Iloprost increases RANKL production}

Receptor activator of nuclear factor $\kappa \mathrm{B}$ ligand (RANKL) is a cytokine with pleiotropic functions deeply involved in control of the immune system, and increased in inflammation [24]. Among PBMCs it is mainly produced by $\mathrm{T}$ cells [33]. Here we investigated the effect of iloprost on this cytokine. Iloprost increases RANKL production by PBMCs in cultures both after 5 days of infusion and 


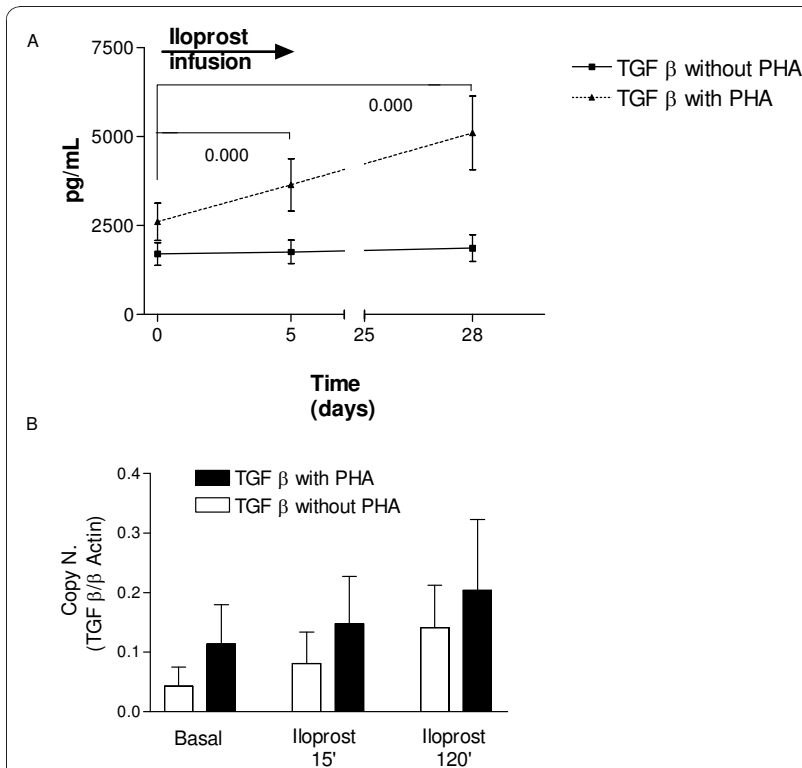

Figure 4 lloprost treatment increases TGF $\beta$ production from PBMCs after stimulus with PHA. TGF $\beta$ was measured in the culture supernatants of PBMCs from SSC patients treated with iloprost at baseline and after treatment ( 5 days of daily treatment, 28 days after the last infusion), cultures were stimulated or not with PHA which predominantly stimulates T cells. A. Graph shows the level of TGF $\beta$ supernatants 24 hrs after stimulus with PHA (dotted line) or without (continuous line). Symbols represent mean and SD, for all the patients, $p$ values were calculated with the Wilcoxon test, significant values are displayed. B. In vitro challenge of PBMCs culture with iloprost for 15 and 120 min, after 24 hrs of PHA or without further stimulus. Graph shows the TGF $\beta$ in PBMCs, TGF $\beta$ expression was corrected for expression of the housekeeping gene $\beta$ actin. Bars represent mean and SD of five independent experiments.

28 days after the last infusion (Figure 5A), whereas it has no effect on serum RANKL (data not shown). In vitro PBMC stimulation with iloprost confirmed this in vivo effect (Figure 5B). These data agree with recent studies [34-36] in which RANKL increased following stimulus with PGE2. Iloprost increases serum IL-2.

IL-2 is a cytokine deeply involved in the control of T cell development and function [25], and controls Treg suppressor function [38]. Here we demonstrate that iloprost increases IL-2 levels of about $15 \%$ after 5 days $(\mathrm{p}=0.008)$ and that this increase persists after the first course (about $40 \%, \mathrm{p}=0.007$ vs baseline). To determine whether the effects of iloprost on TGF $\beta$ and RANKL production are mediated by IL-2, we incubated PBMCs from buffy coats with IL-2 and found that it had no effect on these cytokines (data not shown).

\section{Iloprost does not affect IFN $\gamma$ levels}

IFN $\gamma$ stimulates the production of pro-inflammatory cytokines such as TNF $\alpha$ by macrophages [26]. It has a pleiotropic immune function [27], and may be involved

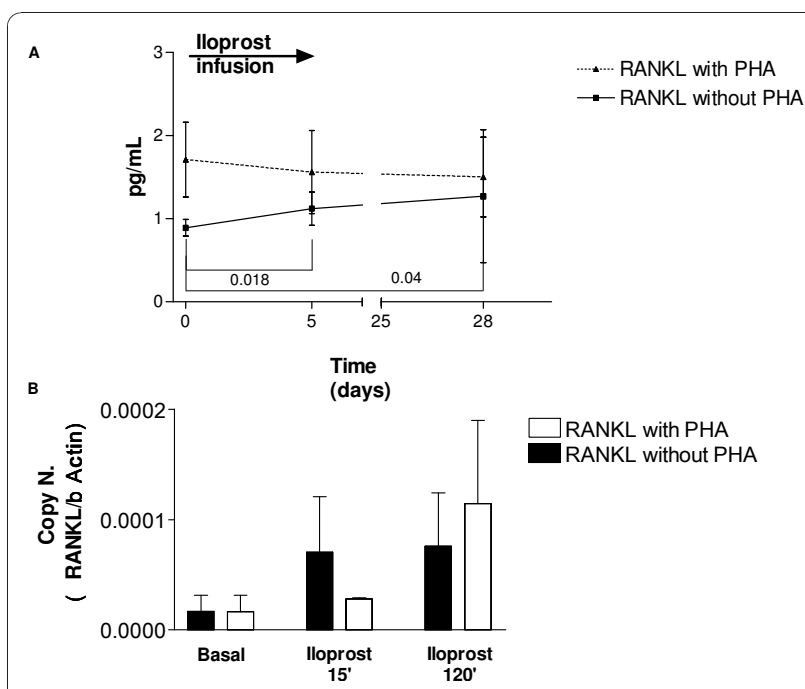

Figure 5 Iloprost treatment increases RANKL production from PBMCs. RANKL was measured in the culture supernatants of PBMCs from SSC patients treated with iloprost at baseline and after treatment ( 5 days of daily treatment, 28 days after the last infusion), cultures were stimulated or not with PHA which predominantly stimulates T cells. A. Graph shows the level of RANKL supernatants $24 \mathrm{hrs}$ after stimulus with PHA (dotted line) or without (continuous line). Symbols represent mean and SD, for all the patients, $p$ values were calculated with by Student's paired t test, significant values are displayed. B. In vitro challenge of PBMCs culture with iloprost for 15 and 120 min, after 24 hrs of PHA or without further stimulus. Graph shows the RANKL in PBMCs, RANKL expression was corrected for expression of the housekeeping gene $\beta$ actin. Bars represent mean and SD of five independent experiments.

in controlling $\mathrm{T}$ cell homeostasis $[41,42]$. Iloprost does not affect serum and supernatant IFN $\gamma$ (data not shown) in keeping with its lack of any effect on monocyte TNF production.

\section{Discussion}

Prostaglandin I 2 is a metabolite of arachidonic acid that has been shown to have anti-inflammatory functions $[21,28,29]$, however, the cellular and molecular mechanisms of PGI2-mediated anti-inflammatory effects remain to be determined. Here we evaluated the effect of iloprost, a PGI2 analogue, widely used in the treatment of $\mathrm{SSc}$, on $\mathrm{T}$ cells sub-populations and on pro-inflammatory cytokines.

This study shows that infusion of iloprost, according to the standard protocol to treat Raynaud's phenomenon in SSc patients, reduces $\mathrm{T}$ cells in the peripheral blood, especially TNF $\alpha$ producing T cells, according to previous in vitro [17-19] and in vivo [21] studies. The mechanism underling this effect was shown by Jorres et al. [19] that found that iloprost reduces TNF $\alpha$ transcriptional activity and decreases TNF $\alpha$ mRNA stability in human peripheral blood mononuclear leukocytes stimulated with LPS; Our study is the first evaluation of the 
effect of iloprost on TNF $\alpha$ production and T cell subsets in SSc. Our finding that iloprost acts on T cells only and not on monocytes is in contrast with Di Renzo et al.'s observation of a reduction of both monocytes and $\mathrm{T}$ cells [21]. This discrepancy may be attributable to the fact that they infused iloprost for $16 \mathrm{~h} /$ day for 7 days as required for critical limb ischemia. Our data show that iloprost reduces both the total amount of TNF $\alpha$ positive T cells and their ability to secrete TNF $\alpha$ after an antigenic stimulus. The role of TNF $\alpha$ in autoimmune diseases is well known, and it is currently a target for monoclonal antibody in diseases such as rheumatoid arthritis [30]. Its reduction by iloprost may thus be an important plus in the evaluation of therapeutic options.

Our study demonstrates a decrease in Treg after 5 days of iloprost infusion in vivo, associated with enhancement of their ability to produce TGF $\beta 1$ in response to immune stimulation. This effect could be due to a generic immunomodulation by iloprost through a systemic increase in IL-2 production, as it is well known that this cytokine is deeply involved in the control of $\mathrm{T}$ cell development and function [25], and it controls Treg suppressor function [38]. Our study demonstrates that iloprost consistently increases serum IL-2 and that this increase persists 28 days after the last infusion. Here we show that IL 2 effect on TGF $\beta 1$ production is not direct, but may be mediated trough other cell types in vivo. Recently a role for dendritic cells in the mediation of iloprost anti-inflammatory activity has been postulated $[31,32]$

The role of TFG $\beta$ in determining the suppressor ability of Tregs is currently under debate [33], TGF $\beta$ is crucial in determining the ability of Tregs to convert Foxp3- $\mathrm{T}$ cells into Foxp3 $+\mathrm{T}$ cells by a mechanism of infectious tolerance [34]. Recent data suggest an important role for Treg cells in the pathogenesis of autoimmune diseases [35], and it has been suggested that their number is increased, whereas their function is impaired, in SSc $[10,30]$. It may thus be supposed that the reduction in Treg number coupled with the increase in their TGF $\beta$ production may be critical for SSc therapy.

We measured the levels of RANKL in serum and in supernatants because this molecule is important in inflammation and in the control of immune function [24] and expected they would be reduced after iloprost similarly to the reduction in TNF. After iloprost instead we found an increase in RANKL levels both as protein and as gene copies number. This could be interpreted as a class effect of prostaglandins, since recent studies [34-36] have demonstrated an increase in RANKL in cells after incubation with PGE2; moreover Conaway and colleagues demonstrated that both PGE2 and PGI2 were able to enhance osteoclast activity that is mainly under RANKL control [36]. However the RANKL increase is not due to IL-2 increase as demonstrated by the lack of IL-2 effect on in vitro PBMCs.

Our data demonstrated that iloprost does not influence IFN $\gamma$ production. This cytokine is particularly involved in the inflammatory reaction of monocytes/ macrophages and induces their TNF $\alpha$ secretion [26]; hence the lack of effect of iloprost on IFN is in line with the absence of its effect on monocyte TNF $\alpha$ production.

\section{Conclusions}

This study suggests that iloprost has specific antiinflammatory and immunomodulating effects: it reduces TNF $\alpha$ production by $\mathrm{T}$ cells without influence on TNF $\alpha$ monocyte production; it reduces the Tregs number, but ameliorates their function probably trough an increase in IL-2 and directly increases RANKL. Hence the therapeutic use of iloprost in SSc patients may be useful not only as vasodilator and antifibrotic, but also as immunomodulator agent.

\section{List of abbreviations}

SSc: Systemic sclerosis; Treg: T regulatory cells; PG: Prostaglandin; PBMCs: peripheral blood mononuclear cells; PHA: phytohemoagglutinin; RANKL: Receptor activator of nuclear factor $\kappa$ B ligand.

\section{Acknowledgements}

This work was supported by an unconditioned grant from the Italfarmaco SpA Italy, a grant from the Fondazione Internazionale Ricerche Medicina Sperimentale (FIRMS) Compagnia San Paolo, a grant from the Ministry for Education, the Universities and Research (MIUR) and from the Regione Piemonte "Ricerca Sanitaria Finalizzata 2008bis". M.A. Cristofaro was supported by a fellowship from the MIUR, P. D'Amelio and F. Sassi were supported by a fellowship from the Regione Piemonte. S. Patanè was supported by a fellowship from the Italian Association for Cancer Research (AIRC). Iloprost used in vitro was kindly provided by Italfarmaco SpA.

\section{Author details}

${ }^{1}$ Gerontology Section, Department of Surgical and Medical Disciplines, University of Torino, Italy. ${ }^{2}$ CeRMS (Center for Research and Medical Studies), A.O.U. San Giovanni Battista, Torino, Italy. ${ }^{3}$ Division of rheumatology "Ordine Mauriziano" Hospital, Torino, Italy. ${ }^{4}$ Department of Orthopaedics, A.O.U. San Giovanni Battista, Torino, Italy. ${ }^{5}$ Department of Genetics, Biology and Biochemistry - University of Torino, Torino, Italy.

\section{Authors' contributions}

PD designed the study and analysed the data. MAC, FS, GB performed the FACS analyses and the ELISA measurements. LD, LV, IR, SP performed the real time experiments MS, RP selected and treated the patients. All the authors critically revised the data, participate in the drafting of the manuscript and approved its final version.

\section{Competing interests}

The authors declare that they have no competing interests.

Received: 10 March 2010 Accepted: 15 December 2010 Published: 15 December 2010

\section{References}

1. Jimenez $\mathrm{SA}$, Derk $\mathrm{CT}$ : Following the molecular pathways toward an understanding of the pathogenesis of systemic sclerosis. Ann Intern Med 2004, 140:37-50. 
2. Hussein MR, Hassan HI, Hofny ER, Elkholy M, Fatehy NA, Abd Elmoniem AE, Ezz El-Din AM, Afifi OA, Rashed HG: Alterations of mononuclear inflammatory cells, CD4/CD8+ T cells, interleukin 1beta, and tumour necrosis factor alpha in the bronchoalveolar lavage fluid, peripheral blood, and skin of patients with systemic sclerosis. J Clin Pathol 2005, 58:178-84.

3. Kalogerou A, Gelou E, Mountantonakis S, Settas L, Zafiriou E, Sakkas L: Early $T$ cell activation in the skin from patients with systemic sclerosis. Ann Rheum Dis 2005, 64:1233-5.

4. Parel Y, Aurrand-Lions M, Scheja A, Dayer JM, Roosnek E, Chizzolini C: Presence of $\mathrm{CD} 4+\mathrm{CD} 8+$ double-positive $T$ cells with very high interleukin-4 production potential in lesional skin of patients with systemic sclerosis. Arthritis Rheum 2007, 56:3459-67.

5. Gustafsson R, Totterman TH, Klareskog L, Hallgren R: Increase in activated T cells and reduction in suppressor inducer T cells in systemic sclerosis. Ann Rheum Dis 1990, 49:40-5.

6. Riccieri V, Parisi G, Spadaro A, Scrivo R, Barone F, Moretti T, Bernardini G, Strom R, Taccari E, Valesini G: Reduced circulating natural killer T cells and gamma/delta T cells in patients with systemic sclerosis. J Rheumatol 2005, 32:283-6.

7. Del Galdo F, Jimenez SA: T cells expressing allograft inflammatory factor 1 display increased chemotaxis and induce a profibrotic phenotype in normal fibroblasts in vitro. Arthritis Rheum 2007, 56:3478-88.

8. Fujii H, Hasegawa M, Takehara K, Mukaida N, Sato S: Abnormal expression of intracellular cytokines and chemokine receptors in peripheral blood $T$ lymphocytes from patients with systemic sclerosis. Clin Exp Immunol 2002, 130:548-56.

9. Vila J, Isaacs JD, Anderson AE: Regulatory T cells and autoimmunity. Curr Opin Hematol 2009, 16:274-9.

10. Radstake TR, van Bon L, Broen J, Wenink M, Santegoets K, Deng Y, Hussaini A, Simms R, Cruikshank WW, Lafyatis R: Increased frequency and compromised function of T regulatory cells in systemic sclerosis (SSc) is related to a diminished CD69 and TGFbeta expression. PLoS One 2009, 4: e5981.

11. Steen V, Denton CP, Pope JE, Matucci-Cerinic M: Digital ulcers: overt vascular disease in systemic sclerosis. Rheumatology (Oxford) 2009, 48(Suppl 3):iii19-24.

12. Wigley FM, Wise RA, Seibold JR, McCloskey DA, Kujala G, Medsger TA, Steen VD, Varga J, Jimenez S, Mayes M, Clements PJ, Weiner SR, Porter J, Ellman M, Wise C, Kaufman LD, Williams J, Dole W: Intravenous iloprost infusion in patients with Raynaud phenomenon secondary to systemic sclerosis. A multicenter, placebo-controlled, double-blind study. Ann Intern Med 1994, 120:199-206.

13. Korn JH, Halushka PV, LeRoy EC: Mononuclear cell modulation of connective tissue function: suppression of fibroblast growth by stimulation of endogenous prostaglandin production. J Clin Invest 1980, 65:543-54.

14. Goldstein RH, Polgar P: The effect and interaction of bradykinin and prostaglandins on protein and collagen production by lung fibroblasts. J Biol Chem 1982, 257:8630-3.

15. Stratton R, Shiwen X, Martini G, Holmes A, Leask A, Haberberger T, Martin GR, Black CM, Abraham D: lloprost suppresses connective tissue growth factor production in fibroblasts and in the skin of scleroderma patients. J Clin Invest 2001, 108:241-50.

16. Stratton R, Rajkumar V, Ponticos M, Nichols B, Shiwen X, Black CM, Abraham DJ, Leask A: Prostacyclin derivatives prevent the fibrotic response to TGF-beta by inhibiting the Ras/MEK/ERK pathway. Faseb J 2002, 16:1949-51.

17. Medsger TA, Silman AJ, Steen VD, Black CM, Akesson A, Bacon PA, Harris CA, Jablonska S, Jayson MI, Jimenez SA, Krieg T, Leroy EC, Maddison PJ, Russell ML, Schachter RK, Wollheim FA, Zacharaie H: A disease severity scale for systemic sclerosis: development and testing. J Rheumatol 1999, 26:2159-67.

18. Czeslick EG, Simm A, Grond S, Silber RE, Sablotzki A: Inhibition of intracellular tumour necrosis factor (TNF)-alpha and interleukin (IL)-6 production in human monocytes by iloprost. Eur I Clin Invest 2003, 33:1013-7.

19. Jorres A, Dinter H, Topley N, Gahl GM, Frei U, Scholz P: Inhibition of tumour necrosis factor production in endotoxin-stimulated human mononuclear leukocytes by the prostacyclin analogue iloprost: cellular mechanisms. Cytokine 1997, 9:119-25.
20. Zhou W, Blackwell TS, Goleniewska K, F O'Neal J, Fitzgerald GA, Lucitt M, Breyer RM, Peebles RS Jr: Prostaglandin 12 analogs inhibit Th1 and Th2 effector cytokine production by CD4 T cells. J Leukoc Biol 2007, 81:809-17.

21. Zhou W, Hashimoto K, Goleniewska K, O'Neal JF, Ji S, Blackwell TS, Fitzgerald GA, Egan KM, Geraci MW, Peebles RS Jr: Prostaglandin 12 analogs inhibit proinflammatory cytokine production and T cell stimulatory function of dendritic cells. J Immunol 2007, 178:702-10,

22. Di Renzo M, Pieragalli D, Meini S, De Franco V, Pompella G, Auteri A, Pasqui AL: lloprost treatment reduces TNF-alpha production and TNF-RII expression in critical limb ischemia patients without affecting IL6. Prostaglandins Leukot Essent Fatty Acids 2005, 73:405-10

23. Jaffar Z, Wan KS, Roberts K: A key role for prostaglandin 12 in limiting lung mucosal Th2, but not Th1, responses to inhaled allergen. J Immunol 2002, 169:5997-6004

24. Leibbrandt A, Penninger JM: RANK/RANKL: regulators of immune responses and bone physiology. Ann N Y Acad Sci 2008, 1143:123-50.

25. Malek TR: The biology of interleukin-2. Annu Rev Immunol 2008, 26:453-79.

26. Mosser DM, Edwards JP: Exploring the full spectrum of macrophage activation. Nat Rev Immunol 2008, 8:958-69.

27. Hu X, Ivashkiv LB: Cross-regulation of signaling pathways by interferongamma: implications for immune responses and autoimmune diseases. Immunity 2009, 31:539-50.

28. Hashimoto K, Graham BS, Geraci MW, FitzGerald GA, Egan K, Zhou W, Goleniewska K, O'Neal JF, Morrow JD, Durbin RK, Wright PF, Collins RD, Suzutani T, Peebles RS Jr: Signaling through the prostaglandin 12 receptor IP protects against respiratory syncytial virus-induced illness. J Virol 2004, 78:10303-9.

29. Nagao K, Tanaka H, Komai M, Masuda T, Narumiya S, Nagai H: Role of prostaglandin 12 in airway remodeling induced by repeated allergen challenge in mice. Am J Respir Cell Mol Biol 2003, 29:314-20.

30. Murdaca G, Colombo BM, Puppo F: Anti-TNF-alpha inhibitors: a new therapeutic approach for inflammatory immune-mediated diseases: an update upon efficacy and adverse events. Int I Immunopathol Pharmacol 2009, 22:557-65.

31. Muller T, Durk T, Blumenthal B, Herouy Y, Sorichter S, Grimm M, Panther E, Cicko S, Norgauer J, Idzko M: lloprost has potent anti-inflammatory properties on human monocyte-derived dendritic cells. Clin Exp Allergy 40:1214-21.

32. Idzko M, Hammad H, van Nimwegen M, Kool M, Vos N, Hoogsteden HC, Lambrecht BN: Inhaled iloprost suppresses the cardinal features of asthma via inhibition of airway dendritic cell function. J Clin Invest 2007, 117:464-72.

33. Shevach EM: Mechanisms of foxp $3+\mathrm{T}$ regulatory cell-mediated suppression. Immunity 2009, 30:636-45.

34. Andersson J, Tran DQ, Pesu M, Davidson TS, Ramsey H, O'Shea JJ, Shevach EM: CD4+ FoxP3+ regulatory T cells confer infectious tolerance in a TGF-beta-dependent manner. J Exp Med 2008, 205:1975-81.

35. Banica L, Besliu A, Pistol G, Stavaru C, Ionescu R, Forsea AM, Tanaseanu C, Dumitrache S, Otelea D, Tamsulea I, Tanaseanu S, Chitonu C, Paraschiv S, Balteanu M, Stefanescu M, Matache C: Quantification and molecular characterization of regulatory $T$ cells in connective tissue diseases. Autoimmunity 2009, 42:41-9.

36. Conaway HH, Diez LF, Raisz LG: Effects of prostacyclin and prostaglandin E1 (PGE1) on bone resorption in the presence and absence of parathyroid hormone. Calcif Tissue Int 1986, 38:130-4.

doi:10.1186/1471-2172-11-62

Cite this article as: D'Amelio et al: Iloprost modulates the immune response in systemic sclerosis. BMC Immunology 2010 11:62. 